УДК 659.126:339.37]330.47

DOI: $10.25140 / 2411-5215-2020-4(24)-26-33$

Михайло Газуда, Мирослава Стеців

\title{
УПРАВЛІННЯ РОЗВИТКОМ РИТЕЙЛ-БРЕНДИНГУ В УМОВАХ ЦИФРОВІЗАЦІЇ ЕКОНОМІКИ
}

\author{
Михаил Газуда, Мирослава Стецив \\ УПРАВЛЕНИЕ РАЗВИТИЕМ РИТЕЙЛ-БРЕНДИНГА \\ В УСЛОВИЯХ ЦИФРОВИЗАЦИИ ЭКОНОМИКИ
}

\author{
Mykhailo Hazuda, Myroslava Stetsiv \\ RETAIL BRANDING DEVELOPMENT MANAGEMENT \\ IN THE CONDITIONS OF DIGITALIZATION OF THE ECONOMY
}

У статті окреслено необхідність створення дісвих управлінських підходів до забезпечення розвитку брендингового середовища, зокрема формування ритейл-брендингу як необхідної маркетингової складової з метою ефективного функиіонування багатогранних сфер $і$ видів економічної діяльності в умовах посилення прочесу изирровізації $i$ трансформаційних змін у межах територіальної економічної системи. Акиентовано увагу на взаємозумовленості та взаємозв'язку між результативністю функиіонування галузей економіки $i$ впровадженням ичифрових комп'ютерних технологій та формування інтернет-економіки загалом. Зумовлюється пошук механізму впровадження цифрових комунікаційних технологій у напрямі підвищення результативності управлінського процесу у пріоритетних сферах начіональної економіки $i$, зокрема, сфери аграрного бізнесу як вагомої складової продовольчої безпеки країни та ї̈ регіонів. Зазначено, щзо доступ до публічної інформачї̈, глобалізація, очифрування даних, що поступово проникають в украӥнську економіку, мають позитивний соиіальний характер. Обтрунтовано потребу окреслення управлінських підходів до створення ефективної системи організаџї конкурентоспроможного бізнессередовища з метою ефективного функиіонування економіки країни та ї̈ регіонів. Доповнюючим елементом формування результативного управлінського процесу повинно бути спрямування зусиль і поєднання інтересів державних органів влади, органів самоврядування, суб'єктів господарювання $і$ бізнес структур у посиленні иифровізації та впровадженні иифрових комунікаційних технологій у багатогранних сферах і видах економічної діяльності в межах територіальної економічної системи. Доцільним є акиентувати увагу на формування ритейл-брендингу, який в умовах ицифрової трансформачії є необхідною складовою маркетингової діяльності в жорстких умовах конкурентноі боротьби між виробниками продукиї̈ за увагу споживача.

Ключові слова: управлінських процес; розвиток; формування ритейл-брендингу; маркетингова діяльність; иџифровізація економіки; трансформаційні зміни.

Рис.: 1. Бібл.: 18.

В статье обозначена необходимость создания действенных управленческих подходов к обеспечению развития брендинговой среды, в частности формирование ритейл-брендинга как необходимой маркетинговой составляющей с иелью эффективного функиионирования многогранных сфер и видов экономической деятельности в условиях усиления процесса ицирровизачии и трансформационных изменений в пределах территориальной экономической системы. Акиентировано внимание на взаимообусловленности и взаимосвязи между результативностью функиионирования отраслей экономики и внедрением цифровых компьютерных технологий и формированием интернет-экономики в целом. Обусловлено поиск механизма внедрения иифровых коммуникачионных технологий в направлении повышения результативности управленческого процесса в приоритетных сферах национальной экономики и, в частности сферы аграрного бизнеса, как весомой составляющей продовольственной безопасности страны и ее регионов. Отмечено, что доступ к публичной информаиии, глобализачия, очифровка данных, постепенно проникают в украинскую экономику, имеют положительный социальный характер. Обоснована необходимость определения управленческих подходов к созданию эффективной системы организации конкурентоспособной бизнес-среды с иелью эффективного функиионирования экономики страны и ее регионов. Дополняющим элементом формирования результативного управленческого процесса должно быть направление усилий и сочетание интересов государственных органов власти, органов самоуправления, субъектов хозяйствования и бизнес-структур в усилении ичирровизации и внедрении циифровых коммуникационных технологий в многогранных сферах и видах экономической деятельности в пределах территориальной экономической системы. Целесообразно акцентировать внимание на формирование ритейл-брендинга, который в условиях иифровой трансформации является необходимой составляющей маркетинговой деятельности в жестких условиях конкурентной бороть между производителями продукиии за внимание потребителя.

Ключевые слова: управленческий прочесс; развитие; формирование ритейл-брендинга; маркетинговая деятельность; иифровизачия экономики; трансформачионные изменения.

Рис.: 1. Библ.: 18.

The article outlines the need to create effective management approaches to ensure the development of the branding environment, in particular the formation of retail branding as a necessary marketing component for the effective functioning of multifaceted areas and types of economic activity in the process of digitalization and transformational change within the territorial economic system. Emphasis is placed on the interdependence and relationship between the effectiveness of the economy and the introduction of digital computer technology and the formation of the Internet economy in general. The search of the

(C) Газуда М. В., Стеців М. Р., 2020 
mechanism for the introduction of digital communication technologies in order to increase the effectiveness of the management process in priority areas of the national economy is determined and in particular the agribusiness, as an important component of food security of the country and its regions.It is noted that access to the public information, globalization, digitization of data that are gradually penetrating the ukrainian economy, have a positive social character.The need to outline management approaches to the creation of an effective system of organization of a competitive business environment for the effective functioning of the economy of the country and its regions is substantiated.A complementary element of the formation of an effective management process should be the direction of efforts and combination of interests of public authorities, self-government bodies, economic entities and business structures in strengthening digitalization and introduction of digital communication technologies in multifaceted spheres and economic activities within the territorial economic system.It is advisable to focus on the formation of retail branding, which in terms of digital transformation is a necessary component of marketing activities in the harsh conditions of competition between manufacturers for consumer attention.

Keywords: management process, development, formation of retail branding, marketing activity, digitalization of economy, transformational changes.

Fig.: 1. References: 18

JEL Classification: M31; L81; O14

Постановка проблеми. Забезпечення ефективного функціонування економічної системи в сучасних умовах перманентності трансформацій тісно пов'язано 3 впровадженням цифрових комп'ютерних технологій та формуванням інтернет-економіки загалом. Тренди сучасного життя - SMM, цифрові платежі, електронний документообіг та віддалена торгівля стали для вітчизняного ринку своєрідним імперативом, до викликів якого складно адаптуватися суб'єктам господарювання. Ефективне функціонування багатогранних сфер і видів економічної діяльності, зокрема і сфери аграрного господарювання $\epsilon$ стратегічно важливим для забезпечення збалансованого розвитку та економічного зростання регіонів України й повинен забезпечуватися з урахуванням цифрових трансформаційних підходів у межах формування нової вебекономіки. Сучасні виклики нової епохи зумовили необхідність широкого поширення маркетингу поряд із формуванням брендингового середовища, що дало поштовх до вивчення та теоретичного застосування ритейл-брендингу як засобу формування міцних конкурентних переваг. При цьому ритейл-брендинг є ключовою основою маркетингової діяльності в умовах жорсткої конкуренції та процесу цифровізації економіки. Водночас інтернет-технології дозволили маркетингу стати максимально проактивним, збільшити рівень проникнення на основі детального оцінювання потенційних покупців, де концептуальними засадами дієвого маркетингу виступають реклама та піар-технології.

Трансформаційні зміни останніх років, що зумовили появу цифрового простору, активно впливають на формування бізнес- і бренд-середовища функціонування бізнесу, загалом, його взаємодію зі споживачами, ринком, державними інституціями. Зазначені зв'язки є наслідком безперервних техніко-технологічних змін, безпосередньо впливаючи на галузевий економічний розвиток, а підсилення їхньої ролі під впливом світової пандемії COVID-19 зумовило необхідність формування підходів до забезпечення збалансованого розвитку сфер і видів економічної діяльності, стабільності життя суспільства. Розуміння важливості застосування цифрового сегмента в структурі ритейл-брендингу в межах аграрного бізнесу, пошук альтернатив для підвищення рівня привабливості бізнесу у сфері аграрного господарювання, об'єднання зусиль владних і бізнесових структур регіону стають дедалі актуальнішими. Зважаючи на викладене, дослідження взаємозв'язку і взаємопроникнення цифрового сектору економіки й аграрної сфери через призму управління розвитком ритейл-брендингу окреслює актуальність наукового пошуку.

Аналіз останніх досліджень і публікацій. Теорія та практика брендингу загалом та ритейл-брендингу зокрема $є$ об'єктом вивчення маркетологів зі всього світу. Так, Ф. Котлер, Дж. Залтман, М. Бейкер та інші [15] сформулювали потужну теоретичну підоснову тематики. Їхні фундаментальні дослідження дали змогу розвивати наукові підходи до формування брендингу не виключно у практичній площині, а перенести іiї в наукове поле й досліджувати феномен теоретичного підгрунтя. Закономірно, що зміни економічної системи та їхній вплив на маркетинг і брендинг зокрема можна прослідкувати й у су- 
часних працях основоположника галузі Ф. Котлера, А. Сетіавана, Х. Картаджай, Р. Каннан, Р. Кей [14-16]. У цьому контексті варто зауважити феномен гіперпідключеності, що досліджується паралельно з брендинговими концептами сучасності Б. Веллманом [18] та групою вчених В. Свамінаттан, А. Сорессу, Я. Стеенкамп, Т. Гуінн, Б. Шмітт [17]. До речі, П. Темпорал розглядав брендинг як складний маркетинговий процес створення бренда, його відповідної юридичної реєстрації та управління [12]. В Україні проблема також активно досліджується Н. Архіповою, А. Гулей, Я. Матвіївою, І. Пономаренко, Ю. Робул [9].

Окремими підходами відзначаються наукові розвідки таких закордонних учених, як П. Друкер [4], В. Кноррінг [6], С. Анхольт [13], а також вітчизняних - М. Бойко [1], С. Велещук [2] та інших, у напрямі вивчення брендингу й зокрема ритейл-брендингу в багатогранних сферах і видах економічної діяльності регіональної економіки, розглядувані через призму управління просторовим розвитком.

Виділення недосліджених частин загальної проблеми. Незважаючи на напрацювання вітчизняних і закордонних науковців, необхідністю зумовлюється пошук механізму впровадження цифрових комунікаційних технологій у напрямі підвищення результативності управлінського процесу в пріоритетних сферах національної економіки і сфери аграрного бізнесу зокрема.

Мета статті. Метою статті є окреслення особливостей формування управлінських підходів до забезпечення розвитку ритейл-брендингу в умовах цифровізації економіки.

Виклад основного матеріалу. Класична брендингова теорія трактує розуміння поняття ритейл-брендингу як масштабної маркетингової діяльності зі створення довготривалих переваг товару певного виробника над іншими товарами в межах жорстких умов конкурентного середовища. Реалізується така діяльність через вплив на споживача товарним знаком, фірмовим пакуванням, рекламними зверненнями чи іншими атрибутами, що вирізняють товар серед інших та формують його привабливий образ [5]. Закономірно, що сутністю та критичною цінністю такої діяльності є бренд. Найфундаментальніший дослідник цієї галузі маркетингу Ф. Котлер у своїх дослідженнях постійно модифікував, удосконалював власне бачення бренда. Початково сформоване вченим визначення, що бренд - знак, ім'я, символ, малюнок чи їх поєднання, що служать для ідентифікації продавця та виокремлення його від конкурентів, у процесі зміни наголосів та стрімкого поширення ринкових досліджень автор помітно змодифікував. У пізніших працях представлено трактування: «Бренд - складне поняття, яке може виражати шість значень: 1) атрибути; 2) вигоди; 3) цінності; 4) культура; 5) індивідуальність; 6) користувач» [7].

Еволюція сутнісного розуміння бренда й ритейл-бренда, на відміну від окремо взятої індивідуалізованої торгової марки, зумовлюється комплексним підходом до процесу створення бренда певної продукції чи товару з метою його продажу в роздрібноторговій мережі. Таким чином, розуміння бренда в ритейлі є уявою у свідомості покупця місцезнаходження для здійснення покупки.

Розвиток брендингового середовища, у глобальному масштабі, тісно пов'язано з посиленням процесів цифровізації економіки та проникненням інтернет-технологій у функціонування різних сфер і видів економічної діяльності. Розширення інтернет-мережі і iii можливостей у країні систематично здійснюються Інтернет-асоціацією України (ІнАУ) у співпраці з дослідницьким холдингом Factum Group Ukraine. Результати їхніх досліджень свідчать, що 71 \% сучасних українців є постійними користувачами Інтернету, що демонструє значну залученість населення та актуалізує використання медіа в будь-якій економічній чи соціальній сфері. Для порівняння, у 2004 р. такий показник становив $12 \%$, у 2009 - $25 \%, 2012$ - $50 \%, 2017$ - 64\%, що демонструє значне пришвидшення росту показника після у період 2010-2012 pp. [8]. За аналізований період ук- 
ГАЛУЗЕВИЙ АСПЕКТ РОЗВИТКУ НАЦІОНАЛЬНОГО ГОСПОДАРСТВА

раїнський споживач став значно відкритішим до споживання глобальної інформації, світових соціальних мереж, індустрій, світової торгівлі. Це, у свою чергу, створило додатковий тиск на вітчизняних виробників та посередників, адже дедалі більша кількість споживачів прагне самостійно купувати в міжнародних торговельних гігантів. Споживачі вимагають кращої ціни, прозоріших умов співпраці продавця з покупцем, швидкості обробки запитів та доставки товару, слідування глобальним трендам тощо.

Крім того, варто звернути увагу на розроблену вищезгаданим холдингом динаміку поширення Інтернету в розрізі типів населених пунктів. Дослідження наочно демонструє, що найбільший приріст користувачів Інтернету за останні 8 років відбувся поміж жителів сільської місцевості.

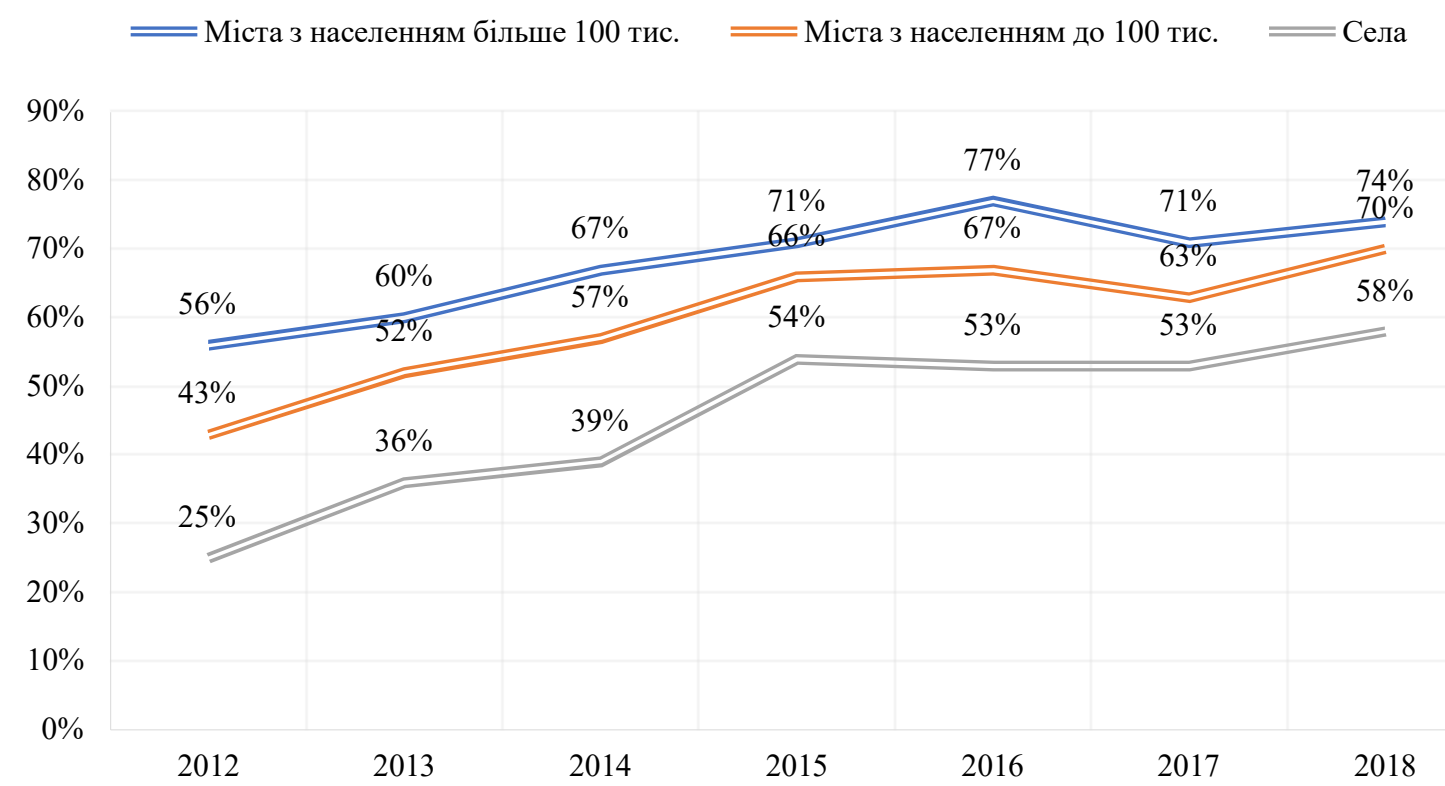

Рис. 1. Динаміка проникнення Інтернету в розрізі населених пунктів (щуорічний замір)*

Примітка. Уся Україна, без АР Крим та окупованих територій України, населення віком 15+ років. Джерело: [8].

Відмічений приріст, як засвідчують дані рис. 1, зумовлений впливом відповідних чинників, зокрема:

1) збільшення кількості кабельних та інтернет-провайдерів, що розширили свої мережі в сільській місцевості;

2) поширення в Україні 3G-зв'язку для широкої аудиторії (діяльність операторів ТриМоб, Інтертелеком, Vodafone Україна, Peoplenet) з 2013 р.;

3) зміна цінової політики продажу мобільних пристроїв у бік доступності, розширення модельних рядів ноутбуків, пізніше планшетів та смартфонів у середньому ціновому сегменті;

4) міграція населення (у тому числі трудова, соціально-економічна, сімейнопобутова, маятникове переміщення людей);

5) природна потреба людей отримувати актуальну інформацію своєчасно та у вільному доступі;

6) потреба спілкування, поширення соціальних мереж.

Доцільно зазначити, що доступ до публічної інформації, глобалізація, оцифрування даних, що поступово проникають в українську економіку, мають позитивний соціальний характер. Однак стануть викликом для локального підприємництва. Зазначене змусить виробників переглянути власні конкурентні переваги, змістить векторне спрямування розвитку в бік співпраці зі споживачем. Сучасний технологічний 
розвиток дозволяє великим підприємствам виробляти значну кількість якісної продукції, зберігати, швидко доставляти іiі навіть у віддалені населені пункти. Водночас маркетинг та брендинг допомагають зробити таку продукцію бажаною, забезпечують іiі конкурентність та збут.

Окремо потрібно акцентувати увагу на ще одній глобальній тенденції, яка характеризуватиметься значним впливом на розвиток ринків найближчим часом. Дослідження Factum group демонструють, що станом на 2019 р. розподіл користувачів за типом доступу глобально змінився. Домашні комп’ютери і навіть ноутбуки становлять 36 та $40 \%$ відповідно, натомість мобільний смартфон став найпопулярнішим засобом доступу з результатом у $66 \%$. Це знову ж доводить, що сучасні тенденції розвитку цифрового сегмента значно впливають на потреби людей, сприяють інформаційній глобалізації, ширшим можливостям навчання, обміну досвідом, співпраці, що, в свою чергу, повинно враховуватися виробниками та дистриб'юторами.

Доречно зауважити, що сучасні українці, особливо мешканці мегаполісів та великих обласних центрів, щоденно використовують набір товарів, співвідносний із тим, що використовується жителями розвинених країн. Часто йдеться навіть про товари тих самих виробників, а отже, глобальних брендів. Водночас потрібно визнати, що регіони, де переважає сільська місцевість і менші населені пункти, більш економічно відсталі. Однак це не свідчить про їхню інформаційну ізоляцію. Населення таких регіонів постійно мігрує в пошуку роботи, здобуття освіти, забезпечення вищого соціального рівня, в результаті чого значна кількість активного населення покидає цю місцевість. На нашу думку, саме глобалізація, доступ до електронної торгівлі та інформації можуть бути рушійною силою для подолання негативних наслідків економічної відсталості.

Необхідність формування дієвої системи управління розвитком ритейл-брендингу у сфері аграрного господарювання, передусім в умовах цифрових трансформацій зумовлюється історичними особливостями галузі, оскільки Україна з давніх-давен була відомим потужним виробником аграрної продукції, а сільське господарство відігравало провідну роль у структурі національної економіки. Крім виготовлення продукції для забезпечення внутрішнього продовольчого ринку, вітчизняні аграрії активно займалися збутом надлишкової продукції, таким чином брали участь у міжнародній торгівлі. Аграрні землі займають близько $70 \%$ загального державного фонду, а в різних областях в аграрному бізнесі працює від 7-8\% (у тимчасово окупованій території Донецької області та Дніпропетровщині) до 30 \% (у Херсонській, Кіровоградській, Черкаській, Тернопільській, Закарпатській областях) населення. За даними державного реєстру статистики, країна експортує продукцію до 190 країн світу, в у 2018 р. саме агросектор влив до економіки країни 38 \% валютної виручки.

Незважаючи на таку стратегічну важливість розвитку галузі, аграрний ринок України перебуває у своєрідній рецесії. Українські вчені наголошують, що світові трансформаційні зміни загострили проблеми організаційно-економічних та фінансовокредитних механізмів управління, що застосовуються такими компаніями. Тому критичною є потреба забезпечення ефективнішого економіко-соціального розвитку, базуючись на перспективних напрямах діяльності, здійснення заходів посилення конкурентних позицій на ринку.

Тенденції розвитку аграрного сектору, зазначені вище, притаманні й Закарпаттю. 3 ресурсного погляду, цей регіон має унікальну екологічну систему, придатну для ведення багатьох видів господарювання. Крім того, етнічно та соціально цей регіон унікальний - в області проживають громади близько ста національностей. Однак в силу історичних, географічних та економічних факторів довгий час область була регіоном з низьким 
розвитком продуктивних сил та індустріального розвитку. Від часу проголошення Україною незалежності, регіонально економіка краю неодноразово радикально реформувалася, однак помилки в управлінських рішеннях, що супроводжували такі реформи зумовили перетворення регіону в депресивну територіальну систему [11]. Однак варто зазначити, що незважаючи на складне становище, за рахунок залучення інвестицій, пошук ефективного використання ресурсного потенціалу, конкуретність малого та середнього бізнесу негативні процеси було частково стабілізовано, проте упродовж останніх 10 років, на жаль, значних зрушень не відбулося.

Зважаючи на викладене вище, а також критичну проблему розвитку аграрної сфери регіону, стимулювання темпів формування його конкурентних переваг, вважаємо за доцільне створення дієвого управлінського середовища у напрямі поглиблення процесів впровадження цифрових технологій. Вважаємо застосування брендингу, зокрема ритейл-брендингу сприятиме зменшенню рівня негативних наслідків вищезгаданих процесів.

Доцільність застосування брендингу обгрунтовуємо перш за все тим, що аграрна регіональна політика в основному спрямована на продовольче забезпечення населення регіону. До прикладу, вирощування винограду, який в силу природних умов $\epsilon$ одною 3 центральних культур сільського господарства сприяє виноробству. Вина Закарпаття, що внесені до каталогів кращих вин України та відзначені нагородами міжнародних виставок, не завжди можуть створити реальну конкуренцію іншим українським виробникам чи імпортованим товарам, що стоять в товарному ряду поруч. Якісна та цінова політика регіонального продукту, часто навіть привабливіша, ніж у аналогічних товарів, однак сучасна ринкова боротьба - це конкуренція брендів, яких у регіоні, на жаль, небагато.

Позитивним для брендингу аграрної сфери в Закарпатті є те, що глобальний вплив на виробництво та реалізацію продукції в регіоні має середнє та мале підприємництво. Динаміка постійного збільшення кількості суб'єктів господарювання дає підстави стверджувати, що галузева та територіальна структура аграрної сфери не залишатиметься статичною. Статистичні дані засвідчують, що з 2010 до 2017 р. валова продукція сільського господарства області збільшилася на 183,1 млн грн, при цьому в 2017 р. частка сільськогосподарських підприємств становила 332,5, а господарств населення - 3688,9 млн грн [10]. Навіть зважаючи на складність виживання такого бізнесу на ринках та потребу конкурувати за збут із промисловими гігантами, малий бізнес мотивованіший, а головне гнучкіший до змін, а отже має більше шансів на успіх.

Основним пріоритетом, і вагомим завданням управлінського процесу забезпечення ефективного господарювання у сфері аграрного розвитку, як вважають окремі науковці, повинна стати реалізація внутрішньої ефективності організації [3]: оптимізування землекористування, раціональне та ефективне використання виробничого потенціалу, інтенсивне залучення новітніх агротехнологій, оптимально обгрунтована на виробництві основних видів продукції диверсифікація виробництва, поглиблення процесів інтеграції, кооперування.

Висновки і пропозиції. Таким чином, дослідження підтвердило потребу окреслення управлінських підходів до створення ефективної системи організації конкурентоспроможного бізнес-середовища 3 метою ефективного функціонування економіки країни та іiі регіонів. Доповнюючим елементом формування результативного управлінського процесу повинно бути спрямування зусиль і поєднання інтересів державних органів влади, органів самоврядування, суб' єктів господарювання та бізнесструктур у посиленні цифровізації та впровадженні цифрових комунікаційних технологій у багатогранних сферах i видах економічної діяльності в межах 
територіальної економічної системи. Особливу увагу потрібно звернути на ритейлбрендинг, який в умовах цифрової трансформації $\epsilon$ необхідною складовою маркетингової діяльності в жорстких умовах конкурентної боротьби між виробниками продукції за увагу споживача. Подальші наукові розвідки стосуватимуться дослідження особливостей використання ритейл-технологій у сфері аграрного господарювання в умовах посилення процесу цифровізації економіки країни та ії регіонів.

\section{Список використаних джерел}

1. Бойко М. Г. Організаційно-економічний механізм формування національного бренду. Teоретичні та прикладні питання економіки. 2010. Вип. 21. С. 304-311.

2. Велещук С. С. Територіальний брендинг як інструмент соціально-економічного розвитку регіону. Сталий розвиток економіки. 2015. № 13. С. 146-152.

3. Волощук К. Б., Волощук В. Р., Кацан А. М. Інвестиційна привабливість та можливості розвитку агропромислових підприємств. Інноваційна економіка. 2020. Вип. 1-2. С. 145-150.

4. Друкер П. Ф. Задачи менеджмента в XXI веке: пер. с англ. Москва : Вильямс, 2003. 313 с.

5. Загородній А. Г., Вознюк Г. Л., Комарницький І. М. Торгівля, маркетинг, реклама: термінологічний словник. Львів : Видавництво Львівської політехніки, 2011. 312 с.

6. Кнорринг В. И. Искусство управления : учебник. Москва : Изд-во БЕК, 1997. 264 с.

7. Котлер Ф. Маркетинг XXI века: пер. з англ. Санкт-Петербург : Нева, 2005. 238 с.

8. Проникнення інтернету в Україні. Дослідження ініційоване ІнНАУ, проведено дослідницьким холдингом Factum Group Ukraine. 2019. URL: https:/inau.ua/sites/default/files/file/ 1910/dani_ustanovchyh_doslidzhen_iii_kvartal_2019_roku.pdf.

9. Робул Ю. В. Предмет та завдання макромаркетингу пов'язані з розвитком цифрових систем. Економічні інновації. 2020. Вип. 2 (75). С. 93-100.

10. Сільське господарство Закарпаття за 2010-2017 роки : статистичний збірник / за ред. Г. Д. Гриник. Ужгород, 2018. URL: http://uz.ukrstat.gov.ua/catalog/2018/zbirnuk04.pdf.

11. Стимулювання регіонального розвитку Закарпатської області : монографія / за ред. Л. Т. Шевчук. Львів, 2008. 241 с. (Сер. «Проблеми регіонального розвитку»). URL: http://ird.gov.ua/irdp/p20080302.pdf.

12. Темпорал П. Эффективный бренд-менеджмент: пер. 3 англ. Санкт-Петербург : Нева, 2016. $288 \mathrm{c}$.

13. Anholt S. Competitive Identity: The New Brand Management for Nations, Cities and Regions. Palgrave Macmillan. 2007.

14. Kannan P., Li H. Digital marketing: A framework, review and research agenda. International Journal of Research in Marketing. 2017. Vol. 1. Pp. 22-45.

15. Kotler P., Kartajaya H., Setiawan I. Marketing 4.0: moving from traditional to digital. Hoboken, New Jersey: Wiley, 2017.

16. Key T. Domains of digital marketing channels in the sharing economy. Journal of Marketing Channels. 2017. Vol. 12. Pp. 27-38.

17. Swaminathan V., Sorescu A., Steenkamp J., O'Guinn T., Schmitt B. Branding in a hyperconnected world: Refocusing theories and rethinking boundaries. Journal of Marketing. 2020. Vol. 84(2). Pp. 24-46.

18. Wellman B. Physical Place and Cyber Place: The Rise of Networked Individualism. International Journal of Urban and Regional Research. 2001. Vol. 25(2). Pp. 227-252. DOI: 10.1111/1468-2427.00309.

\section{References}

1. Boiko, M. (2010). Orhanizatsiino-ekonomichnyi mekhanizm formuvannia natsionalnoho brendu [Organizational and economic mechanism of national brand formation. Teoretychni ta prykladni pytannia ekonomiky]. Teoretychni ta prykladni pytannia ekonomiky - Scientific journal Theoretical and applied issues of economics, 21, pp. 304-311.

2. Veleshchuk, S. (2015). Terytorialnyi brendynh yak instrument sotsialno-ekonomichnoho rozvytku rehionu [Territorial branding as a tool for socio-economic development of the region]. Stalyi rozvytok ekonomiky - Sustainable development of economy, (13), pp. 146-152. 
ГАЛУЗЕВИЙ АСПЕКТ РОЗВИТКУ НАЦІОНАЛЬНОГО ГОСПОДАРСТВА

3. Voloshchuk, K., Voloshchuk, V., Katsan, A. (2020). Investytsiina pryvablyvist ta mozhlyvosti rozvytku ahropromyslovykh pidpryiemstv [Investment attractiveness and opportunities for development of agro-industrial enterprises]. Innovatsiina ekonomika - Innovative economy, 1-2, pp. 145-150.

4. Druker, P. (2003). Zadachi menedzhmenta $v$ XXI veke [Management Challenges in the 21st Century]. Williams.

5. Zahorodnii, A., Vozniuk, H., Komarnytskyi, I. (2011). Torhivlia, marketynh, reklama: terminolohichnyi slovnyk [Trade, marketing, advertising: a glossary]. Lviv Polytechnic Publishing House.

6. Knorrynh V. (1997). Iskusstvo upravleniia [The Art of Management]. BEK Publishing.

7. Kotler, F. Marketing XXI veka [21st Century Marketing]. Neva.

8. Pronyknennia internetu $\mathrm{v}$ Ukraini [Internet penetration in Ukraine. The study was conducted by the research holding Factum Group Ukraine]. https://inau.ua/sites/default/files/file/1910/ dani_ustanovchyh_doslidzhen_iii_kvartal_2019_roku.pdf.

9. Robul, V. (2020). Scope of macro marketing related to the development of digital marketing systems. Ekonomichni innovatsii - Economic innovations, 2(75), pp. 93-100.

10. Hrynyk, H. (Ed.) (2018). Silske hospodarstvo Zakarpattia za 2010-2017 r. : statystychnyi zbirnyk [Agriculture of Transcarpathia for 2010-2017: Statistical collection]. http://uz.ukrstat.gov.ua/ catalog/2018/zbirnuk04.pdf.

11. Shevchuk, L. T. (2008). Stymuliuvannia rehionalnoho rozvytku Zakarpatskoi oblasti [Stimulation of regional development of the Transcarpathian region]. http://ird.gov.ua/irdp/p20080302.pdf

12. Temporal, P. (2016). Effektivnyi brend-menedzhment [Effective brand management]. Neva.

13. Anholt, S. (2007). Competitive Identity: The New Brand Management for Nations, Cities and Regions. Palgrave Macmillan.

14. Kannan, P., Li, H. (2017). Digital marketing: A framework, review and research agenda. International Journal of Research in Marketing, 1, pp. 22-45.

15. Kotler, P., Kartajaya, H., Setiawan, I. (2017). Marketing 4.0: moving from traditional to digital. Hoboken, New Jersey: Wiley.

16. Key, T. (2017). Domains of digital marketing channels in the sharing economy. Journal of Marketing Channels, 12, pp. 27-38.

17. Swaminathan, V., Sorescu, A., Steenkamp, J., O’Guinn, T., Schmitt, B. (2020). Branding in a hyperconnected world: Refocusing theories and rethinking boundaries. Journal of Marketing, 84(2), pp. 24-46.

18. Wellman, B. (2001). Physical Place and Cyber Place: The Rise of Networked Individualism. International Journal of Urban and Regional Research, 25(2), pp. 227-252. doi:10.1111/1468-2427.00309.

|Газуда Михайло Васильович - доктор економічних наук, професор, професор кафедри економіки і підприємництва, ДВНЗ «Ужгородський національний університет» (вул. Університетська, 14, м. Ужгород, 88000, Україна).

Газуда Михаил Васильевич - доктор экономических наук, профессор, профессор кафедры экономики и предпринимательства, ДВНЗ «Ужгородский национальный университет» (ул. Университетская, 14, г. Ужгород, 88000, Украина).

Hazuda Mykhailo - Doctor of Economics, Professor, Uzhhorod National University (14 University Str., 88000 Uzhhorod, Ukraine).

E-mail: misha.gazuda@uzhnu.edu.ua

ORCID: https://orcid.org/0000-0003-3947-5997

Стеців Мирослава Романівна - аспірантка, ДВНЗ «Ужгородський національний університет» (вул. Університетська, 14, м. Ужгород, 88000, Україна).

Стецив Мирослава Романовна - аспирантка, ДВНЗ «Ужгородский национальный университет» (ул. Университетская, 14, г. Ужгород, 88000, Украина)

Stetsiv Myroslava - PhD student, Uzhhorod National University (14 University Str., 88000 Uzhhorod, Ukraine).

E-mail: stetsivmira@gmail.com

ORCID: https://orcid.org/0000-0001-7022-7110

Газуда М., Стеців М. Управління розвитком ритейл-брендингу в умовах цифровізації економіки. Проблеми $і$ перспективи економіки та управління. 2020. № 4(24). С. 26-33. 